\title{
VIDEO PORNO SEBAGAI SALAH SATU FAKTOR PENYEBAB TERJADINYA TINDAK PIDANA KESUSILAAN YANG DILAKUKAN OLEH ANAK
}

\author{
PORNOGRAPHIC VIDEO AS ONE FACTOR CAUSING \\ SEXUAL HARASSMENT CRIME PERFORMED BY CHILDREN
}

\author{
Andi Dewi Pratiwi \\ andidewipratiwii@gmail.com \\ Bagian Ilmu Hukum Fakultas Hukum Universitas Sulawesi Barat
}

\begin{abstract}
Abstrak
Kemerosotan moral Bangsa Indonesia tentang seks ini, terlihat saat beberapa kasus yang terjadi di mana seks dilakukan oleh para pesohor, guru, PNS, politisi sampai di kalangan pelajar maupun mahasiswa dengan tidak malu. Penelitian ini bertujuan engetahui seberapa besar pengaruh video porno terhadap anak sebagai pelaku tindak pidana kesusilaan dan mengetahui bentuk penanggulangan yang relevan dalam meminimalisir pengaruh video porno terhadap prilaku anak. Penelitian ini dilakukan di polrestabes Makassar LAPAS klas I Makassar, dan BAPAS Makassar, pengumpulan data dilakukan dengan cara wawancara dan study literature, data dianalisis secara deskriptif. Hasil penelitian menunjukkan bahwa video porno merupakan factor yang berpengaruh kuat dibandingkan dengan factor factor lainnya dala tindak pidana kesusilaan yang dilakukan oleh anak. Tontonan yang berupa gambar-gambar porno akan memberikan rangsangan seks terhadap anak. Dengan adanya dorongan- dorongan seks ditambah dengan rasa ingin tahu yang besar pada anak berimbas pada terjadinya tindak pidana kesusilaan. Upaya meminimalisir pengaruh video porno dalam tindak pidana kesusilaan yang dilakukan oleh anak dapat dilakukan dengan cara pre-emitif, preventif, dan represif.
\end{abstract}

Kata kunci: video porno, tindak pidana kesusilaan, pre-emptif, preventif, represif.

\begin{abstract}
Moral decline Indonesian people about sex, seen as some cases where sex is done by celebrities, teachers, civil servants, politicians up among students and students with no shame. This study aims to find out to extent pornographic videos influence children in doing sexual harassment crime and determine relevant actions in minimizing the influence of pornographic videos. The research was conducted at Makassar city subregional police, Makassar class I penal institution, and Makassar rehabilitation center. The data were also obtained through a library research conducted by reading books, legal journal, and regulation related to the topic of this study. The result reveals that pornographic videos have stronger influence compared to the other factors causing sexual harassment crime committed by children. The pornographic images provide sexual stimulus to children. The stimulus, together with high curiosity in children result in the occurrence sexual harassment crime. To minimize this problem, some effort can be done including pre-emptive, preventive, and repressive effort . pre-emptive effort are conducted by teaching good values / norms as well as providing strong religious education, started from the family. Preventive effort are conducted through supervision in the school environment, religious and legal counseling, and the improvement of children's social environment. Finally, the repressive effort can be conducted through punishment, guidance, and supervision.
\end{abstract}

Keywords: video porn, criminal acts of decency, pre-emptive, preventive, repressive. 


\section{PENDAHULUAN}

Pandangan dan pembatasan serta definisi mengenai pornografi dari Pasal-pasal yang ada di dalam Kitab Undang-Undang Hukum Pidana (selanjutnya disingkat KUUHP) tidak tercantum dengan jelas sehingga belum cukup untuk dijadikan dasar atau landasan hukum bagi para penegak hukum untuk mengambil tindakan hukum. Karena kelemahan yang ada di KUUHP tersebut hingga pada tahun 2008 diundangkanlah Undang-Undang Nomor 44 Tahun 2008 Tentang Pornografi (Undang-undang Pornografi). Sebagai landasan filosofis Undang-undang Pornografi tersebut sebagaimana ditegaskan di dalam Konsideran Undang-undang Pornografi adalah bahwa Negara Kesatuan Republik Indonesia adalah negara hukum yang berdasarkan Pancasila dengan menjunjung tinggi nilai-nilai moral, etika, akhlak mulia, dan kepribadian luhur bangsa, beriman dan bertakwa kepada Tuhan Yang Maha Esa, menghormati kebinekaan dalam kehidupan bermasyarakat, berbangsa, bernegara, serta melindungi harkat dan martabat setiap warga negara.

Melihat perkembangan berita di media massa, kasus video porno di Indonesia semakin meningkat. Rangkaian tayangan pornografi semakin hari semakin marak. Awal Juni 2010 masyarakat digemparkan dengan munculnya video porno di berbagai media yang diduga dilakukan oleh Ariel dan Cut Tari. Video yang berdurasi lebih 8 menit tersebut direkam menggunakan kamera digital. Berbagai kalangan mulai praktisi pendidikan, pembela hak-hak anak, psikolog, ahli seksologi, ahli IT, ulama sampai Presiden pun sibuk mengomentari masalah ini. Dengan adanya kasus ini, berbagai permasalahan dan skandal besar yang mengguncang negeri ini yang sebelumnya mendominasi media seolah menguap begita saja. Beredarnya video porno yang menjadikan selebritis sebagai peran utamanya, menunjukkan betapa parahnya praktek seks bebas dikalangan mereka, sekaligus menjadi ikutan oleh masyarakat, lebih khusus bagi kaum muda yang haus dengan sifat keingintahuannya tentang hal itu.

Kemerosotan moral Bangsa Indonesia tentang seks ini, terlihat saat beberapa kasus yang terjadi di mana seks dilakukan oleh para pesohor, guru, PNS, politisi sampai di kalangan pelajar maupun mahasiswa dengan tidak malu, bahkan ironisnya lagi malah menjadi bangga dengan perbuatan yang sangat hina tersebut. Bagaimana maraknya video porno di media internet bukan kesalahan media ataupun keberadaan internet itu sendiri. Awalnya video mirip Luna Maya banyak menyebar lewat jejaring sosial, namun media ini tidak dapat disalahkan. Sejak tidak ada internet pun, prostitusi misalnya memang sudah marak di masyarakat. Tanpa facebook ataupun 
Youtube bukan berarti prostitusi ini akan musnah. Sama seperti kasus ini, bukan serta merta disebarkan di Facebook, lalu kita kemudian membatasi Facebook di Indonesia. Sejauh ini pemerintah telah melakukan hal maksimal mengurangi penyebaran sejumlah konten tidak layak di internet melalui aturan yang jelas, dan dijadikan pedoman untuk menyangkut suatu kasus.

Maraknya video porno di kalangan anak bukan hanya didorong oleh rasa penasaran semata. Namun adalah bentuk ekspresi aktualisasi diri yang salah. Keinginan dianggap oleh anak sebagai sebuah bentuk informasi terkini atau up to date artinya mereka tidak mau ketinggalan informasi. Parahnya, fenomena ini akan ditiru oleh anak. Kalau sekarang pelajar saja sudah suka menonton video porno dan tidak ada pencegahannya, dalam jangka panjang akan berimbas pada penurunan kualitas moral, akhlak dan budi pekerti. Konkretnya akan meningkat kasus kriminalitas yang berkaitan dengan tindak asusila. Di Makassar pernah terjadi kasus perkosaan yang melibatkan anak sebagai pelaku perkosaan. Alasan mereka melakukan perkosaan itu, karena kerap menonton video porno. Temuan ini adalah kenyataan pahit yang harus ditelan, karena sekalipun yang terlibat sebagai pelaku perkosaan masih anak-anak, sebenarnya anak-anak itu adalah korban video porno itu.

Dari tahun ke tahun kasus asusila makin meningkat tajam. Data dari Polrestabes Makassar menunjukkan pada Tahun 2012 ada 16 kasus asusila yang dilakukan oleh anak dari 22 kasus, Tahun 2013 ada 11 kasus asusila yang dilakukan oleh anak dari 44 kasus dan Tahun 2014 ada 13 kasus asusila yang dilakukan oleh anak dari 57 kasus. Dalam kasus peredaran video porno ini, sesungguhnya yang menjadi akar permasalahan adalah mudahnya mendapatkan video porno ini. Di negara kita, yang dasar negaranya adalah Pancasila dan sebagian besar penduduknya agamais, justru sangat mudah mendapatkan video porno. Pesatnya pornografi di kalangan anakanak tidak terlepas dari rasa penasaran dan keingintahuan kaum muda terhadap masalah seks. Kalaupun ada, pengetahuan itu kurang memuaskan rasa keingin tahuan kaum muda. Untuk memuaskan rasa penasaran dan keingintahuannya, merekapun mencari tahu dengan coba-coba tanpa pendamping yang bisa membimbing dengan benar, mereka membaca berbagai liputan tentang seks, buku dan gambar porno. Belum lagi pornografi yang dengan mudah diserap melalui cyber perss atau peredaran video porno yang mudah didapat.

Yang lebih parah, masyarakat setelah mengunduh video-video tersebut, kemudian disebarkan ke teman-teman, bahkan ada yang menontonnya bersama-sama seperti nonton sepak bola, sambil makan kacang dan minum bir. Video-video tersebut pun jatuh ke tangan anak-anak. 
Demi masa depan, moral dan akhlak remaja yang akan menjadi tulang punggung bangsa Indonesia di kelak kemudian hari, ada baiknya jika kita menghentikan penyebaran video porno tersebut. Tujuan penelitian ini adalah untuk mengetahui seberapa besar pengaruh video porno terhadap tindak pidana kesusilaan yang dilakukan oleh anak.

\section{METODE PENELITIAN}

\section{Populasi dan Sampel}

Penelitian ini yang menjadi Populasi adalah seluruh pelaku tindak pidana a-susila yang dalam hal ini pelakunya adalah anak di Kota Makassar. Terdapat 45 kasus tindak pidana kesusilaan yang dilakukan oleh anak dan pelaku secara keseluran akan menjadi responden penelitian ini. Untuk Polisi, Jaksa, Hakim dan pihak yang berkompeten pada LAPAS Kelas I Makassar dan BAPAS Makassar, diambil sampel dengan teknik purposive sampling sehingga berdasarkan teknik ini dari pihak Kepolisian, Jaksa, Hakim, serta pihak yang berkompeten pada LAPAS Kelas I Makassar dan BAPAS Makassar masing-masing 2 (dua) orang yang dianggap memahami dan mengetahui tentang hal-hal yang menjadi objek penelitian.

\section{Jenis dan Sumber Data}

Dalam penelitian ini penulis menggunakan dua jenis data, yaitu Data primer dan Data sekunder. Data primer, yaitu data yang secara langsung diperoleh di lapangan yang berasal dari para anak sebagai pelaku kejahatan, pihak Polrestabes Makassar, pihak Kejaksaan Negeri Makassar, hakim pada Pengadilan Negeri Makassar, serta petugas LAPAS Kelas I Makassar dan BAPAS Makassar. Data sekunder, yaitu data yang diperoleh melalui studi kepustakaan, dokumen, arsip-arsip yang relevan dengan objek penelitian utamanya dalam hal ini kejahatan yang dilakukan oleh anak.

\section{Teknik Pengumpulan Data}

Untuk keperluan pengumpulan data digunakan wawancara yaitu tanya jawab secara langsung pada responden dan narasumber yang telah ditentukan sebelumnya selain itu juga dilakukan penelaahan litertaur-literatur dan dokumen-dokumen yang berhubungan dengan masalah yang dibahas dalam penelitian ini. 


\section{Analisis Data}

Data yang diperoleh dalam penelitian ini selanjutnya dianalisis secara kualitatif, yakni analisis yang bersifat mendeskripsikan data yang diperoleh baik data primer maupun data sekunder kemudian diberi penjelasan dan kesimpulan untuk menjawab permasalahan yang ada.

\section{HASIL}

Faktor usia merupakan faktor yang mempunyai pengaruh terhadap seseorang dalam melakukan kejahatan. Usia sering kali berpengaruh terhadap kemampuan berpikir dan bertindak atas diri seseorang. Menurut pengalaman medis dan pendidikan ilmiah, terdapat perbedaan antara anak dan orang dewasa, yaitu tidak hanya berbeda secara kuantitatif saja (dalam arti besar kecilnya), akan tetapi juga badan dan jiwanya berfungsi jauh berbeda. Seorang anak, dalam melakukan suatu tindakan terkadang hanya mengandalkan nalurinya saja, tanpa berpikir lebih jauh akan akibatnya. Dalam usia yang masih muda (belum matang) seorang anak lebih cenderung ingin serba "mencoba". Sehingga di usia yang belum matang tersebut, daya pikir anak masih labil, tergantung masukan-masukan atau faktor-faktor lain, yang akan melahirkan suatu perbuatan. Baik itu perbuatan yang bersiat baik atau bersifat buruk. Umur adalah salah satu hal yang membedakan jenis kejahatan. Pada usia remaja, kejahatan yang biasa dilakukan berorientasi pada kejahatan dikategorikan ringan, sedangkan pada orang dewasa dapat lebih bervariasi, namun faktor usia bukan faktor yang berdiri sendiri, yang dapat mempengaruhi kenakalan anak, melainkan saling berpengaruh dengan faktor lain.

Terlihat bahwa anak sebagai pelaku tindak pidana kesusilaan di Kota Makassar, lebih banyak dilakukan oleh anak di masa puber dan masa pemuda antara umur 12 - 18 tahun, hal ini dikarenakan pada usia-usia tersebut terdapat kematangan fungsi jasmaniah ditandai dengan berkembangnya tenaga fisik yang melimpah-limpah yang menyebabkan tingkah laku anak keliatan kasar, canggung, berandal, kurang sopan, liar dan lain-lain. Sejalan dengan berkembangnya fungsi jasmaniah, perkembangan intelektual pun berlangsung sangat intensif sehingga minat pada pengetahuan dan pengalaman baru pada dunia luar sangat besar terutama yang bersiat kongkret, karenanya anak puber disebut sebagai fragmatis atau utilitas kecil, di mana minantnya terarah pada kegunaan-kegunaan teknis.

Menurut Teori Psikoseksual oleh Sigmund Freud, pada tubuh manusia terdapat bagianbagian tertentu, yang apabila mendapat rangsangan akan memberikan kenikmatan dan daerah 
dari bagian tubuh yang mendapat kenikmatan tersebut berpindah-pindah. Misalnya mulut sebagai pusat kenikmatan maka perkembangan psikosesksual berada pada tahap oral. Sigmund Freud membagi fase perkembangan atas beberapa bagian, Fase oral (lahir - 12 / 18 bulan) bayi mendapat sumber kenikmatan di daerah mulut seperti menghisap dari puting susu Ibu, Fase anak (12 / 18 bulan - 3 tahun) anak mendapatkan kepuasan seksual melalui membuang air besar, pusat pemuasan berada pada daerah anal, Phallic (3 - 6 tahun) daerah pemuasan beralih pada daerah genital, Latency (6 - puber) saat relatif calm, Genital (puber - dewasa) matura adult sexuality. Dapat dilihat hubungan antara Teori psikoseksual dengan hasil penelitian bahwa pelaku tindak pidana kesusilaan dilakukan pada usia puber (antara 12 - 18 tahun). Karena pada usia-usia tersebut, anak dalam masa pertumbuhan fisik yang sangat hebat dan mulai timbul ciri-ciri sekunder (jakun, bulu ketiak, dan bulu disekitar genitalia). Pada usia tersebut, kematangan seks dan kemampuan bereproduksi sudah ada, namun tidak diikuti dengan perkembangan psikologi yang matang, sehingga mereka belum mampu bertanggung jawab, menggebu-gebu, mempunyai rasa ingin tahu yang besar serta dipengaruhi dorongan-dorongan seks yang masih baru dan mungkin belum diketahuinya.

Terkadang kematangan seks dan kemampuan bereproduksi sudah ada pada mereka, namun mereka belum mampu untuk bertanggung jawab. Perkembangan organ-organ seksual anak yang disertai dengan timbulnya dorongan-dorongan seks yang masih baru dan mungkin belum diketahuinya, belum mampu dipertanggungjawabkan dan hanya mengikuti kepuasan sesaat dan tidak berpikir dewasa, sehingga hal ini sering menimbulkan masalah-masalah seksual yang merupakan dampak dari besarnya pengaruh video porno pada anak yang berimbas pada masalah hukum misalnya keinginan untuk mencoba melakukan tindakan a-susila. Harus disadari bahwa betapa besar pengaruh yang dimainkan oleh lingkungan pergaulan anak, terutama sekali disebabkan oleh konteks kuluturalnya. Dalam situasi sosial yang menjadi semakin longgar, anakanak kemudian menjauhkan diri dari keluarganya untuk kemudian menegakan eksistensi dirinya yang dianggap sebagai tersisih dan terancam. Mereka lalu memasuki satu unit keluarga baru dengan subcultural baru yang sudah delinkuen sifatnya.

Sehubungan dengan peristiwa ini, Sutherland mengembangkan teori Association Defferential yang menyatakan bahwa anak menjadi delinkuen disebabkan oleh partisipasinya di tengah-tengah suatu lingkungan sosial yang ide dan teknik delinkuen tertentu dijadikan lingkungan sosial yang ide dan teknik delinkuen tertentu dijadikan sebagai sarana yang efisien 
untuk mengatasi kesulitan hidupnya. Karena itu semakin luas anak bergaul, semakin intensif relasinya dengan Anak Nakal, akan menjadi semakin lama pula proses berlangsungnya asosiasi deferensial tersebut dan semakin besar pula kemungkinan anak tadi benar-benar menjadi anak nakal dan kriminal. Dalam hal ini pernanan orangtua untuk menyadarkan dan mengembalikan kepercayaan anak tersebut serta harga dirinya sangat diperlukan. Perlu mendidik anak agar bersikap formal dan tegas supaya mereka terhindar dari pengaruh-pengaruh yang datang dari lingkungan pergaulan yang kurang baik. Bagi anak yang mengisi waktu senggangnya dengan bacaan-bacaan yang buruk, maka hal itu akan berbahaya dapat menghalang-halangi mereka untuk berbuat hal-hal yang baik. Demikian pula tontonan yang berupa gambar-gambar porno akan memberikan rangsangan seks terhadap anak. Rangsangan seks tersebut akan berpengaruh negatif terhadap perkembangan jiwa anak. Ternyata kecanggihan teknologi tidak hanya berpengaruh positif terhadap kehidupan manusia, terutama anak-anak. Mereka bisa dengan mudah mengakses hal-hal yang tidak sesuai dengan umur mereka, sehingga dengan kepolosan jiwanya, mereka akan terpengaruh dan ingin mencobanya.

Hal ini juga berpengaruh dalam kasus tindak pidana kesusilaan yang dilakukan oleh anak. Kebanyakan mereka mendapat pengetahuan tentang hal-hal yang layak dilakukan oleh suamiistri tersebut dalam video-video porno yang dengan mudah dapat diakses, apalagi dengan kecanggihan teknologi video-video tersebut dengan mudah didapatkan dan juga dapat disimpan dalam handphone. VCD porno dan film-film yang hanya layak ditonton oleh orang dewasa juga berperan dalam memberikan pengetahuan tentang hubungan layaknya suami-istri yang seharusnya belum selayaknya disaksikan oleh anak-anak. Video porno berpengaruh terhadap psikologis anak. Sesuai dengan Teori Psikoseksual oleh Sigmund Freud bahwa fase puber adalah fase dimana alat-alat vital telah matang bereproduksi. Dengan adanya rangsangan yang diperoleh dari menonton video-video porno maka pada usia antara 12 - 18 tahun yang disebut usia puber, pada hasil penelitian dapat dilihat anak pada umur tersebut banyak melakukan tindak pidana kesusilaan . Pada usia tersebut, anak dalam masa pertumbuhan fisik yang sangat hebat dan mulai timbul ciri-ciri sekunder (jakun, bulu ketiak, dan bulu disekitar genitalia). Terkadang kematangan seks dan kemampuan bereproduksi sudah ada pada mereka, namun mereka belum mampu untuk bertanggung jawab. Perkembangan organ-organ seksual anak yang disertai dengan timbulnya dorongan-dorongan seks yang masih baru dan mungkin belum diketahuinya, belum mampu dipertanggungjawabkan dan hanya mengikuti kepuasan sesaat dan tidak berpikir dewasa, 
sehingga hal ini sering menimbulkan masalah-masalah seksual yang berimbas pada masalah hukum.

\section{PEMBAHASAN}

Pada penelitian ini terlihat bahwa Video Porno merupakan faktor yang berpengaruh kuat dibandingkan faktor-faktor penyebab lainnya dalam tindak pidana kesusilaan yang dilakukan oleh anak. Tontonan yang berupa gambar-gambar porno akan memberikan rangsangan seks terhadap anak. Hasil dari penelitian ini sesuai dengan Teori Psikoseksual dari Sigmund Freud. Dengan adanya dorongan-dorongan seksual ditambah dengan rasa ingin tahu yang besar sehingga berimbas pada masalah hukum misalnya keinginan untuk mencoba melakukan tindakan a-susila.

Perkembangan bahasa anak usia 10-12 tahun. Ciri perkembangan bahasa pada tahap ini adalah sebagai berikut. Selain ciri yang terdapat dalam anak usia 6-8, 8-10 tahun, maka ada peningkatan kemampuan anak yang menjadi ciri mereka adalah bahwa anak-anak sudah mulai bisa memahami dan menggunakan kalimat kompleks dengan klausa-klausa atau anak-anak kalimat konsesi yang dinyatakan dengan penggunaan: namun demikian, meskipun demikian, walaupun begitu, meskipun begitu, dan sebagainya. Banyak anak-anak yang telah menginternalisasikan kontrol atau pengawasan mereka, mereka yakin dan percaya bahwa mereka sedang berada dalam pengawasan terhadap apa yang terjadi dan merasa lebih bertanggung jawab secara pribadi atas keberhasilan dan kegagalan mereka. Kemandirian atau keberdikarian merupakan suatu ciri utama pribadi mereka yang sangat bernilai/berharga bagi anak-anak (Maidin, 2008). Perubahan-perubahan yang terjadi secara cepat dalam pertumbuhan fisik mereka dapat menyebabkan beberapa anak menjadi sadar diri dan mengeritik diri sendiri anak lainnya mungkin saja diasyikkan dan disibukkan oleh penampilan mereka sendiri (Leden, 2009).

Dalam teori perkembangan fantasi, yang diungkapkan oleh Charlotte Buhler menuliskan bahwa anak pada usia 8-12 tahun adalah masa cerita realistis, yaitu anak mulai senang terhadap cerita-cerita yang nyata (pahlawan, sejarah, biologi, dan lain-lain). Pada masa ini anak sudah mulai berkurang pengaruh fantasinya, sebab pengamatannya sudah mulai tertib. Anak sudah dapat membedakan antara yang khayal dan yang realistis. memasuki masa realism kritis, di mana anak tidak menyukai lagi dongeng yang fantastis, dongeng yang tidak masuk akal. Sekarang ia lebih menyukai cerita yang benar-benar terjadi, cerita yang masuk akal seperti cerita perjalanan, 
cerita roman, dan sebagainya. pada usia 8-12 tahun, merupakan masa analisis. Dalam masa ini anak telah mampu membeda-bedakan sifat dalam mengenal bagian-bagiannya, walaupun hubungan antara bagian itu belum tampak seluruhnya (Effendy, 1989). Fantasinya mulai berkurang, diganti dengan pengamatan yang nyata (realistis = yang nyata). William Stern menulis bahwa pada masa usia anak SD kelas 5 membagi dalam dua masa, yaitu masa mengenal hubungan dan masa mengenal sifat. Masa mengenal hubungan, yakni anak usia 9-10 tahun. Pada usia ini anak mulai mengenai hubungan antara waktu, tempat, dan hubungan sebab-akibat. Sedangkan masa mengenal sifat, yakni usia 10 tahun ke atas. Anak mulai menganalisis pengamatannya sehingga ia mengenal sifat-sifat benda, manusia, dan hewan. Oswald Kroh menuliskan bahwa pada masa usia 10-12 tahun, merupakan masa realisme kritis, yaitu anak mulai mencapai tingkat berpikir secara konkret.

Teori psikoanalisis tentang kriminalitas menghubungkan delinquent dan perilaku criminal dengan suatu "conscience" (hati nurani) yang baik dia begitu menguasai sehingga menimbulkan perasaan bersalah atau ia begitu lemah sehingga tidak dapat mengontrol dorongan-dorongan si individu, dan bagi suatu kebutuhan yang harus dipenuhi segera (Ilyas, 2012). Sigmund Freud, penemu dari Psychoanalysis, berpendapat bahwa kriminalitas mungkin hasil dari "an overactive conscience" yang menghasilkan perasaan bersalah berlebih yang tak tertahankan akan melakukan kejahatan dengan tujuan agar ditangkap dan dihukum. Begitu mereka dihukum maka perasaan berselah mereka akan mereda. Seseorang melakukan perilaku yang terlarang karena hati nurani atau superego-nya begitu lemah atau tidak sempurna sehingga ego-nya (yang berperan sebagai suatu penengah antara superego dan id) tidak mampu mengontrol dorongandorongan dari id (bagian dari kepribadian yang mengandung keinginan dan dorongan yang kuat untuk dipuaskan dan dipenuhi). Id adalah sistem kepribadian yang asli, dibawa sejak lahir. Dari id ini kemudian akan muncul ego dan superego. Saat dilahirkan, id berisi semua aspek psikologik yang diturunkan, seperti insting, impuls dan drives. Karena superego intinya merupakan suatu citra orang tua yang begitu mendalam, terbangun ketika si anak menerima sikap-sikap dan nilainilai moral orang tuanya, maka selanjutnya apabila ada ketiadaan citra seprti itu mungkin akan melahirkan id yang tak terkendali dan berikutnya delinquency (Alam, 2010).

Pendekatan psychoanalytic masih tetap menonjol dalam menjelaskan baik fungsi normal maupun asosial. Meski dikritik, tiga prinsip dasarnya menarik kalangan psikologis yang mempelajari kejahatan, yaitu (1) Tindakan dan tingkah laku orang dewasa dapat dipahami 
dengan melihat pada perkembangan masa kanak-kanak mereka, (2) Tingkah laku dan motifmotif bawah sadar adalah jalin-menjalin, dan interaksi itu mesti diuraikan bila kita ingin mengerti kejahatan, (3) Kejahatan pada dasarnya merupakan representasi dari konflik psikologis. Untuk menetapkan batasan kriminologi yang baku dan dapat diterima oleh semua orang masih merupakan hal yang sulit, hal ini disebabkan banyaknya keadaan-keadaan pemikiran dalam kriminologi, antara lain karena perkembangan penelitian dan perkembangan teori-teori utamanya yang bersifat kontemporer (Adami, 2005). Suatu perbuatan dapat dikategorikan/termasuk perbuatan jahat/kejahatan bila ia mendapat reaksi dari masyarakat. Reaksi tersebut berupa penolakan, karena perbuatan tersebut dianggap tidak sesuai dengan nilai-nilai yang ada didalam masyarakat. Reaksi tersebut berupa penolakan, karena perbuatan tersebut dianggap tidak sesuai dengan nilai-nilai yang ada didalam masyarakat dan hukum tertulis yang dikodifikasikan Negara (undang-undang), meskipun banyak pula nilai-nilai lokal/masyarakat yang dianggap biasa dan bukan merupakan pelanggaran norma di dalam masyarakat, tetapi didalam undang-undang adalah suatu perbuatan yang dikategorikan kejahatan (Ahmadi \& Soleh, 2005).

Menurut Undang-Undang Nomor 44 Tahun 2008 Tentang Pornografi Pengertian pornografi sebagaimana tertuang dalam Pasal 2 Undang-Undang ini adalah: materi seksualitas yang dibuat oleh manusia dalam bentuk gambar, sketsa, ilustrasi, foto, tulisan, suara, bunyi, gambar bergerak, animasi, kartun, syair, percakapan, gerak tubuh, atau bentuk pesan komunikasi lain melalui berbagai bentuk media komunikasi dan/atau pertunjukan di muka umum yang dapat membangkitkan hasrat seksual dan/atau melanggar nilai-nilai kesusilaan dalam masyarakat. Sementara itu Pasal 4 memuat larangan pornografi: Setiap orang dilarang memproduksi, membuat, memperbanyak, menggandakan, menyebarluaskan, menyiarkan, mengimpor, mengekspor, menawarkan, memperjualbelikan, menyewakan, atau menyediakan pornografi yang secara eksplisit membuat, a) persenggamaan, termasuk persenggamaan yang menyimpang, b) kekerasan seksual, c) masturbasi atau onani, d) ketelanjangan atau tampilan yang mengesankan ketelanjangan, e) alat kelamin, atau, f) pornografi anak (Moeljatno, 1984).

Hilman Hadikusuma mengatakan bahwa menarik batas antara belum dewasa dengan sudah dewasa, tidak perlu dipermasalahkan karena pada kenyataannya walaupun orang belum dewasa namun ia telah dapat melakukan perbuatan hukum, misalnya anak yang belum dewasa telah melakukan jual beli, berdagang dan sebagainya, walaupun ia belum berwenang kawin. Menurut Atmasasmita (1995), bahwa kelalaian orang tua terhadap anak akan menimbulkan 
keterlantaran. Keterlantaran yang berkelanjutan tanpa penyelesaian, tindakan kekerasan dan kekejaman yang terus menerus dialami seorang anak, serta eksploitasi tenaga kerja anak secara disengaja dan dibiarkan akan dapat mengakibatkan goncangan dan konflik batin pada diri si anak. Hal tersebut akan sangat berpengaruh pada perkembangan fisik, mental emosinya serta sosialnya.

\section{KESIMPULAN DAN SARAN}

Berdasarkan hasil penelitian yang dilakukan oleh peneliti maka dapat disimpulkan bahwa video Porno merupakan faktor yang berpengaruh kuat dibandingkan faktor-faktor penyebab lainnya dalam tindak pidana kesusilaan yang dilakukan oleh anak. Tontonan yang berupa gambar-gambar porno akan memberikan rangsangan seks terhadap anak. Hasil dari penelitian ini sesuai dengan Teori Psikoseksual dari Sigmund Freud. Dengan adanya dorongan-dorongan seksual ditambah dengan rasa ingin tahu yang besar sehingga berimbas pada masalah hukum misalnya keinginan untuk mencoba melakukan tindakan a-susila. Selain pengaruh video porno, ada beberapa faktor penyebab lainnya, yaitu lingkungan pergaulan bebas, adanya kesempatan, kurangnya perhatian dan pendidikan moral dari orangtua dan melihat orangtua melakukan perbuatan cabul / faktor lingkungan keluarga. Harusnya pemerintah, masyarakat, terutama orangtua menaruh perhatian yang besar terhadap pengaruh adegan-adegan dalam video porno. Dengan memperketat pengawasan dalam lingkungan keluarga dan sekolah dapat meminimalisir pengaruh video porno terhadap anak. Peran pemerintah juga tidak dapat terlepas dalam meminimalisir pengaruh video porno, dengan lebih memperketat pengawasan terhadap situs-

situs internet yang berbau pornografi, bahkan menutup situs-situs yang berbau porno. 


\section{DAFTAR PUSTAKA}

Adami Chazawi. (2005). Pelajaran Hukum Pidana 1. PT. RajaGrafindo Persada. Jakarta.

Ahmadi \& Soleh. (2005). Psikologi Perkembangan. Rineka Cipta. Jakarta.

Alam A.S. (2010). Pengantar Kriminologi. Pustaka Reflika, Makassar.

Atmasasmita Romli. (1995). Kapita Selekta Hukum Pidana Dan Kriminologi. CV. Mandar Maju. Bandung.

Effendy Rusli. (1989). Azas-Azas Hukum Pidana. Lembaga Percetakan dan Penerbitan Universitas Muslim Indonesia. Ujung Pandang.

Ilyas Ami. (2012). Asas-Asas Hukum Pidana. Rangkang Education dan PuKap. Yogyakarta.

Leden Marpaung. (2009). Asas-Teori-Praktik Hukum Pidana. Cetakan Keenam. Sinar Grafika. Jakarta.

Maidin Gultom. (2008). Perlidungan Hukum Terhadap Anak Dalam Sistem Peradilan Anak di Indonesia. PT. Refika Aditama. Bandung.

Moeljatno. (1984). Asas-Asas Hukum Pidana. Cetakan Kedua. Bina Aksara. Jakarta.

Undang-Undang No.44 Tahun 2008 Tentang Pornografi 